\title{
Review
}

\section{Harvesting of Antimicrobial Peptides from Insect (Hermetia illucens) and Its Applications in the Food Packaging}

\author{
Afreen Sultana ${ }^{1}\left(\mathbb{D}\right.$, Hongrong Luo ${ }^{2}(\mathbb{D})$ and Seeram Ramakrishna ${ }^{3, *(D)}$ \\ 1 Department of Food Technology, School of Interdisciplinary Sciences and Technology (SIST), \\ Jamia Hamdard University, New Delhi 110062, India; affo.afreen123@gmail.com \\ 2 Engineering Research Center in Biomaterials, Sichuan University, Chengdu 610064, China; hluo@scu.edu.cn \\ 3 Center for Nanotechnology \& Sustainability, Department of Mechanical Engineering, \\ National University of Singapore, Singapore 117581, Singapore \\ * Correspondence: seeram@nus.edu.sg
}

Citation: Sultana, A.; Luo, H.; Ramakrishna, S. Harvesting of Antimicrobial Peptides from Insect (Hermetia illucens) and Its Applications in the Food Packaging Appl. Sci. 2021, 11, 6991. https:// doi.org/10.3390/app11156991

Academic Editor: Sergio Torres-Giner

Received: 20 June 2021

Accepted: 26 July 2021

Published: 29 July 2021

Publisher's Note: MDPI stays neutral with regard to jurisdictional claims in published maps and institutional affiliations.

Copyright: (c) 2021 by the authors. Licensee MDPI, Basel, Switzerland. This article is an open access article distributed under the terms and conditions of the Creative Commons Attribution (CC BY) license (https:// creativecommons.org/licenses/by/ $4.0 /)$.

\begin{abstract}
About one-third of the total food produced is wasted, rising the concern to adopt proper management. Simultaneously with the increase in population, demand for food is increasing which may lead to scarcity. Adequate packaging is one of the ways to avoid deterioration of food and prevent wastage. In recent years, active packaging has attained interest due to its commendable results in food preservation. Several studies proved that the embodiment of antimicrobial components into the packaging material has the ability to prevent microbial contamination. Antimicrobial peptides (AMP) are newly discovered antimicrobial agents for impregnation into packaging material. Among various sources for AMP, insects have shown great resistivity against a wide spectrum of microorganisms. Insects feed on substances consisting of a varying range of contaminations, which often results in infections. Insects synthesise AMPs to fight such infections and survive in that atmosphere. The disease-causing agents in humans are the same as those found in insects. Hence, AMPs extracted from insects have the potential to fight the microorganisms that act as hazards to human health. This review highlights the harvesting and synthesis of AMPs from Hermetia illucens, which is a promising source for AMP and its applications in the food packaging industry.
\end{abstract}

Keywords: antimicrobial peptides; synthesis; isolation; harvesting; food packaging; active packaging; impregnation

\section{Introduction}

Antimicrobial Peptides can be defined as the molecules of the innate immune system present in all life forms, ranging from bacteria to human beings. The innate immune system is a defence system working non-specifically against injury or infection in the barrier surface [1]. AMPs are composed of a sequence of amino acid ranging from 5 to 50 chains, usually L-amino acids [2]. Most of the AMPs are positively charged peptides (due to a high content of arginine and lysine residues) that are capable of destroying pathogens directly. The benefit of using peptides as antimicrobial agents is that it shows effectiveness against Gram-positive and Gram-negative bacteria, including multidrugresistant bacteria [2,3]. Most of the AMPs function by disrupting the physical structure of the microbial membrane and/or by targeting intracellular bodies [4]. AMPs have proven to have the ability to fight against various health issues due to the presence of immunomodulatory properties [5]. AMPs are effective in preventing skin cancer, treating wound infection and limiting autoimmune diabetes [6-8]. Promising results of AMPs have suggested its use in novel therapeutic drugs [4].

AMPs can be synthesised from animals, plants, protozoa, fungi and bacteria. Among all the species, insects are found to be the largest living entity of AMPs because of their excellent ability to tolerate changes and their resistant property towards pathogens [9]. Insects are considered an excellent source of AMPs because of their huge biodiversity [10]. 
The characterisation of the innate immune system of insects depends on cellular immunity, which includes phagocytosis, and humoral immunity, which includes the excretion of proteins and peptides [11]. The way an insect responds to fight infections can be categorised in two categories: The constitutive response, which is perpetually ready to fight, and the induced response, which takes 1-3 h to generate [12]. The first insect AMP derived was Cecropin from lepidopteran Hyalophora cecropia [13,14]. More than 3000 AMPs are known till now, among which 2301 are isolated from animals. Hermetia illucens (the black soldier fly) is found to be the most propitious source due to its resisting ability against a huge range of pathogens [15]. Hermetia illucens has a strong immune system as it feeds on decaying organism and manure, which contains high amount of pathogens. Figure 1 represents the history of antimicrobial peptides derived from insects.
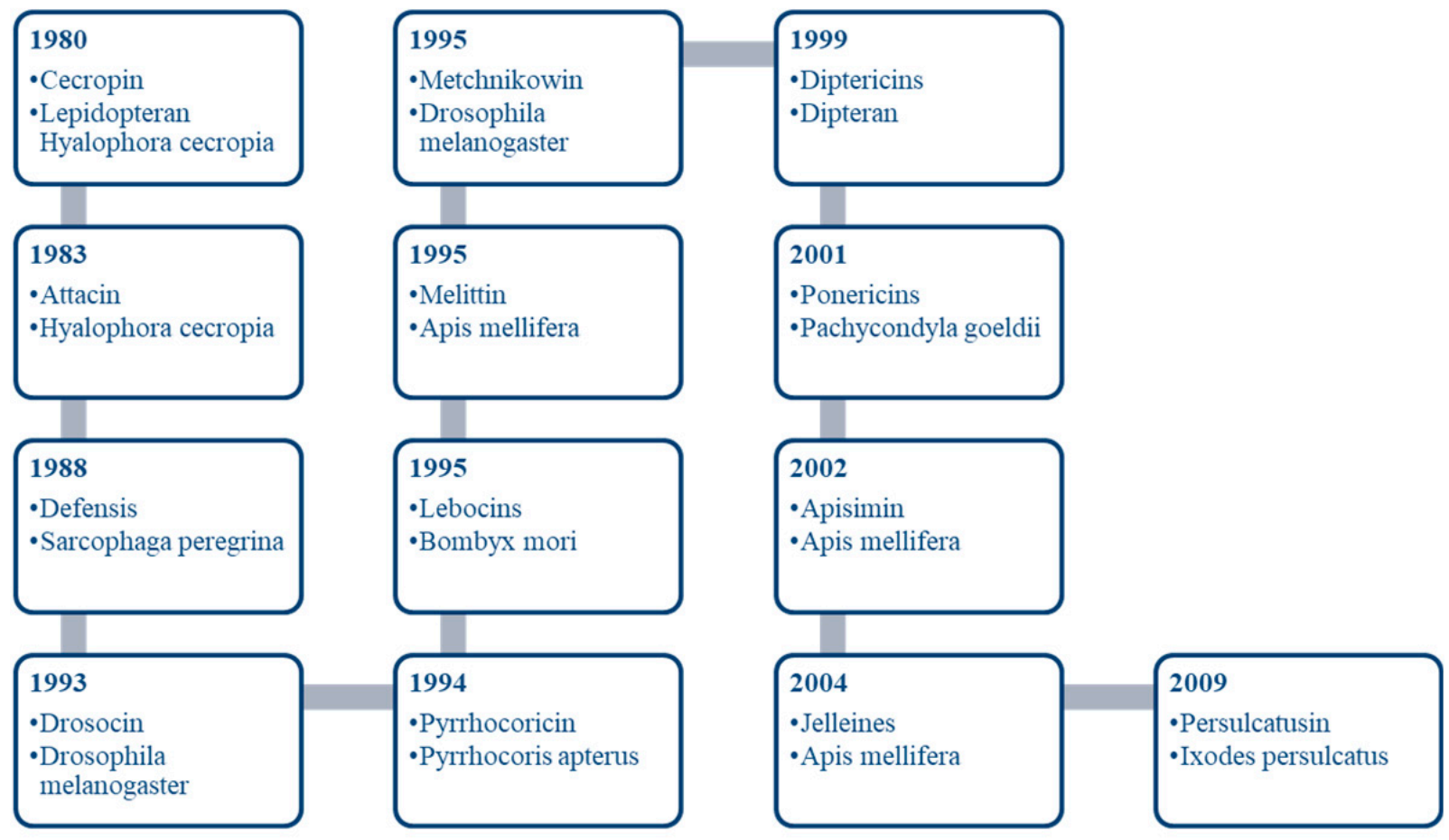

Figure 1. A history of antimicrobial peptides derived from insects.

In recent years, AMPs have gained a huge interest in various fields due to their low toxicity and ability to fight a wide spectrum of pathogenic microbes. One is food packaging, involving studies based on the incorporation of AMPs into packaging material that will be in direct contact with food or interact with the headspace to resist microbial contamination in food [16]. The advantages of using antimicrobial peptides in food packaging over antimicrobial agents [17]:

- Improves food safety by preventing the development of resistant strains of microorganisms;

- Prohibited use of some of the antimicrobial agents due to toxicological reasons;

- Distinctive mode of action of antimicrobial peptides with effective results.

This study focuses on the harvesting of peptides that possess antimicrobial activity along with its applications in food packaging. It also highlights the future scope of antimicrobial peptides in preserving food via active packaging (Figure 2). 


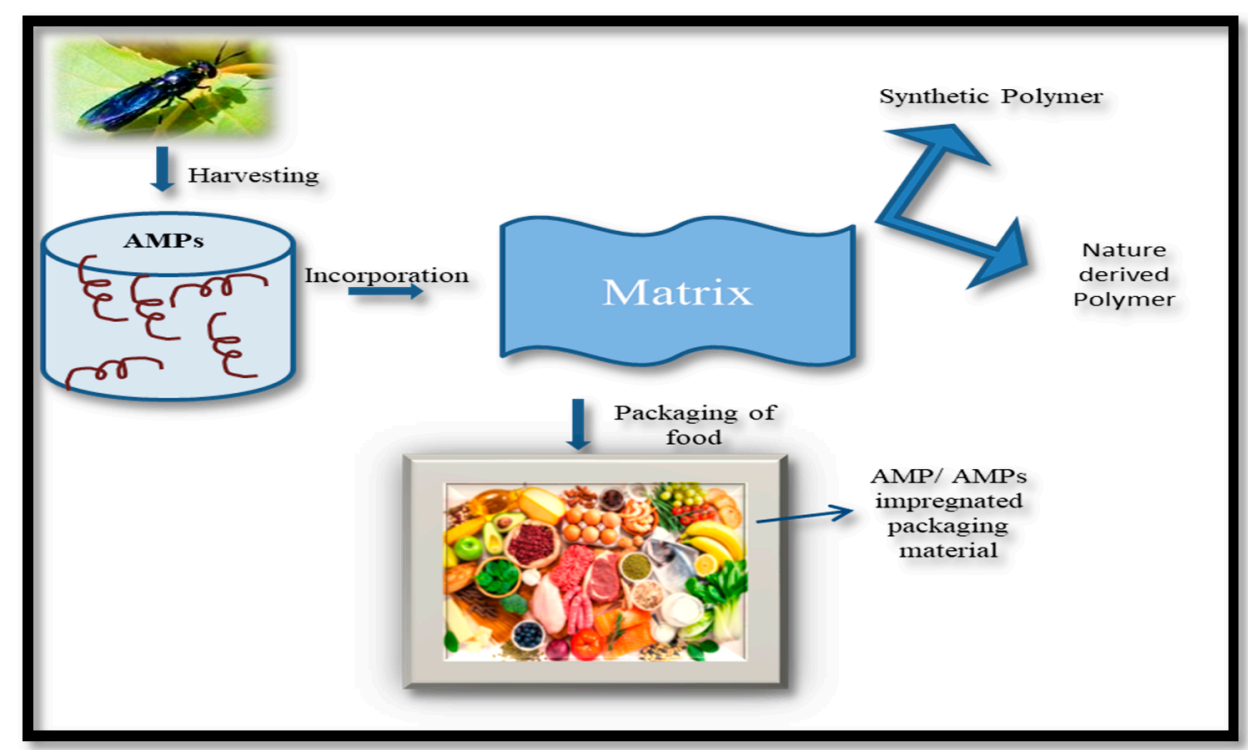

Figure 2. A diagrammatic representation of this study.

\section{Antimicrobial Activity of Peptides Isolated from Insects}

When a microbial agent attempts to invades into an insect's body, the physical barrier acts as a first line of defence, and in case the host is capable of combating the physical barriers, then cellular and humoral responses are activated, which results in production of AMPs [18]. The microbial cell protects the intracellular components and their synthesis via the cell membrane. Any damage to the cellular membrane increases the susceptibility of cell death due to the interference of intracellular components, such as nucleic acids, protein, enzymes and many more with the destructive agent. The complete functional mechanism of AMPs is still under study, but intracellular and extracellular interference is considered as the mode of action [19].

\subsection{Mode of Activity against Bacteria}

At present, only three models on how a peptide becomes attached to a microbial membrane and its ways of functioning are known. These models are different from each other on the basis of the way it disrupts the membrane. The models are discussed below.

\subsubsection{Barrel-Stave Model}

The antimicrobial peptide has two sites: hydrophobic and hydrophilic. In this model, amphipathic $\alpha$ helices form a transmembrane pore, which is a two-step process: the binding of the peptide to the membrane and then the insertion into the hydrophobic area. The hydrophobic surface of the peptide interconnects with the lipid site of the microbial membrane, and the hydrophilic surface is inclined inward, forming an aqueous core (Figure 3). The number of attachments of peptides to the microbial membrane increases, increasing the channel/pore size, ultimately resulting in the death of the microbial cell [20].

\subsubsection{Carpet Model}

The carpet model involves wrapping the microbial membrane with peptides in the form of a carpet instead of inserting it into the hydrophobic core. The mechanism of this model is based on a high concentration of peptides binding to the membrane surface with the hydrophobic head on the outer side of the membrane. It is a three-step process: first, the phospholipid of the microbial membrane interacts with peptides, followed by the phospholipid head of the peptides clustering to the hydrophilic surface, and then, finally, disrupting the membrane (Figure 3) [20]. 


\subsubsection{Toroidal Model}

In the toroidal model, clusters of peptides enter the membrane in a perpendicular orientation, leading to the formation of a curve in an inward direction, with the heads facing towards the centre of hole. This model is similar to barrel-stave model; the only difference is that the toroidal model involves the bending of the membrane inward, resulting in the formation of channels (Figure 3) [21].

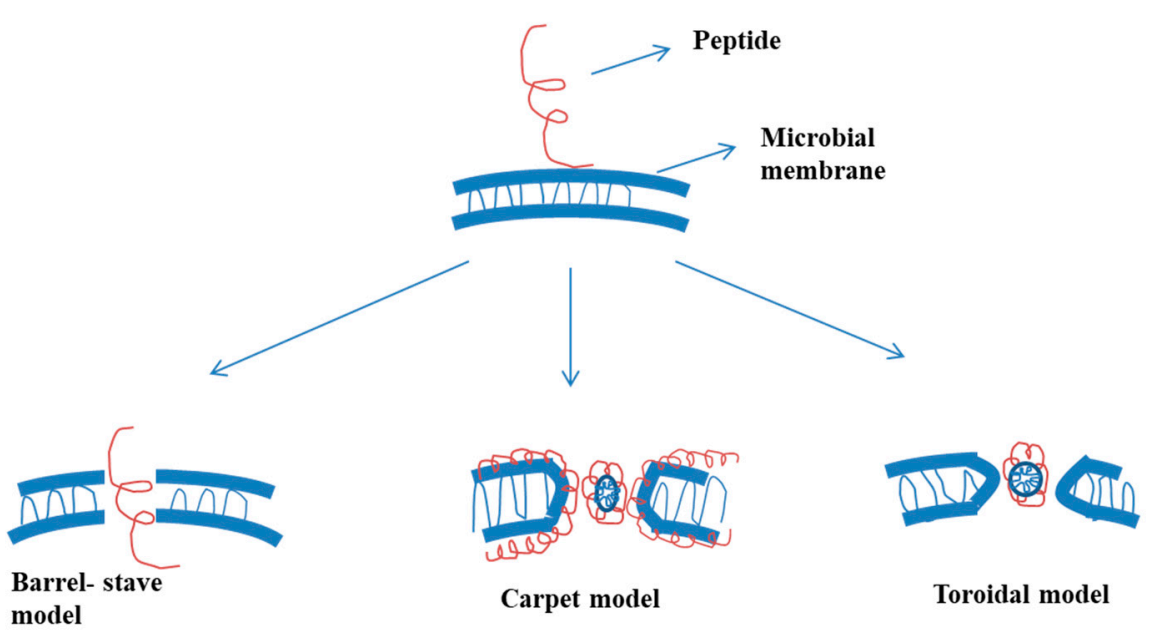

Figure 3. The three pathways of AMPs to disrupt the bacterial membrane.

\subsubsection{Non-Membranolytic Disruption of Bacterial Cell}

In this model, peptides invade the cell without permeating cell membrane and it interferes with synthesis of cell wall, nucleic acid, protein and enzyme activity. Such interference leads to death of microbial cell [20].

\subsection{Mode of Activity against Fungi}

Peptides' mode of action against fungi can occur in three ways, by creating pores, cellular liaising and interfering with intracellular target. The death of a fungal cell by peptides via pore formation begins with a cluster of peptides binding to the surface of the membrane, which forms pores of varying sizes and permits the passage of ions and solutes. In cellular lysis, the peptide, being an amphipathic in nature, binds with the surface and destructs the fungal structure. In the third mechanism, the peptide interacts with the cellular component or synthesises with the fungal cell membrane, leading to death of fungal cell [22].

\subsection{Mode of Activity against Virus}

The antiviral activity of peptides can be either by the interaction with the host cell or with the virus. In a study it was explained that the peptide interacts with glycosaminoglycans (polysaccharide), which are positively charged, and prevents the binding of the virus to the cell membrane by blocking the site [21]. Another mechanism of disruption includes binding of the peptide with the glycoprotein found in the viral envelop, which prevents the binding of the viral cell to other surfaces. Peptides have shown antiviral activity against several viruses, such as the junin virus, herpes simplex virus 1 , nervous necrosis virus and vaccinia virus [23-25].

\section{Categorisation of Antimicrobial Peptides}

The antimicrobial activity of AMP depends on peptide length, charge and hydrophobic nature, and this leads into grouping of AMPs based on some dissimilarities in attributes. Based on the structure, AMPs can be categorised into four types: $\alpha$ helical peptide, cysteinerich peptide, proline-rich peptide and glycine-rich peptide [26]. Some studies have also discussed classification into $\alpha$ helical peptide and $\beta$ sheet peptide. In $\alpha$ helical peptides, 
cysteine is present, which forms an intracellular disulphide bridge, and in $\beta$ sheet peptides, a disulphide bond is found, which is useful in stabilizing the structure as well as crossing the cell membrane [27,28]. According to [29], AMPs can be classified based on the electrostatic charge into cationic (which have positive charge) and non-cationic (consists of negative charge) peptides. Based on the mode of action, peptides are divided into two categories: the membranolytic mechanism and non-membranolytic mechanism [30,31]. AMPs derived from insects are divided into three types: Defensins, Cecropins and peptides with an overrepresentation of Proline and/or Glycine residues [32]. In a study 50 genes encoding putative AMPs were identified from Hermetia Illucens, among which 6 attacins, 26 defensins, 7 cecropins, 10 diptericins and 4 knottin-like peptides were recorded [33]. Table 1 includes the classification of antimicrobial peptides.

Table 1. The classification of antimicrobial peptides.

\begin{tabular}{|c|c|c|c|c|c|}
\hline S.No. & $\begin{array}{l}\text { Criteria for } \\
\text { Classification }\end{array}$ & Peptides & Description & Examples & References \\
\hline \multirow{5}{*}{1.} & \multirow{5}{*}{ Structure } & $\alpha$ helical peptide & $\begin{array}{l}\text { Intramolecular disulphide bridge is formed } \\
\text { by the cysteine }\end{array}$ & Cecropins & [27] \\
\hline & & Cysteine rich peptide & Peptides with cysteine residues & Defensis & [10] \\
\hline & & Glycine rich peptide & Consists of $14 \%$ to $22 \%$ glycine residues & Attacins & [34] \\
\hline & & Proline rich peptide & $\begin{array}{c}\text { Composed of 14-39 amino acids and contains } \\
\text { proline residues }\end{array}$ & Drosocins & [10] \\
\hline & & $\beta$ sheet peptide & $\begin{array}{l}\text { Consist of a disulphide bond, which helps in } \\
\text { stabilizing the conformation }\end{array}$ & Defensis & [35] \\
\hline \multirow[t]{2}{*}{2.} & \multirow[t]{2}{*}{ Mode of action } & Membranolytic & $\begin{array}{l}\text { These peptides enter the microbial cell wall } \\
\text { by disruption }\end{array}$ & Scolopendin 2 & [36] \\
\hline & & Non- membranolytic & Peptide that enters the cell by endocytosis & Scolopendin 1 & [36] \\
\hline \multirow{2}{*}{3.} & \multirow{2}{*}{ Electrostatic charge } & Cationic & Peptide with positive charge & Cecropins & [37] \\
\hline & & Non- cationic & $\begin{array}{l}\text { Peptides with negative charge and isolated } \\
\text { from mammalian epithelia }\end{array}$ & Enkelytin & {$[37]$} \\
\hline
\end{tabular}

\section{Synthesis of Antimicrobial Peptide}

AMPs are found to be useful in various fields of interest, which has led to the study of different methods for the efficient synthesis of peptides from the source. At present, there are three methods of synthesising peptides, which are chemical synthesis, enzymatic synthesis and synthesis using recombinant DNA technology. A brief comparison between all the three mechanism is discussed in the Table 2.

Table 2. A comparison between all the three synthesis techniques.

\begin{tabular}{|c|c|c|c|c|}
\hline S.No. & Type of Synthesis & Advantages & Challenges & References \\
\hline 1. & Chemical & $\begin{array}{l}\text { Easy separation from side products } \\
\text { and impure compounds. }\end{array}$ & Toxic byproducts and low yields. & {$[38,39]$} \\
\hline 2. & Enzymatic & $\begin{array}{l}\text { Helpful in synthesis of short chain } \\
\text { peptides. It also has good } \\
\text { stereo selectivity. }\end{array}$ & $\begin{array}{l}\text { It becomes challenging while } \\
\text { synthesis of long chain peptides. } \\
\text { Low productivity and high cost } \\
\text { of catalyst. }\end{array}$ & {$[39,40]$} \\
\hline 3. & $\begin{array}{c}\text { Recombinant } \\
\text { DNA Technology }\end{array}$ & $\begin{array}{l}\text { Convenient for large } \\
\text { scale production. }\end{array}$ & $\begin{array}{l}\text { Takes more time due to } \\
\text { lengthy process. }\end{array}$ & {$[41,42]$} \\
\hline
\end{tabular}

\subsection{Chemical Synthesis Mechanism}

The synthesis of peptide using chemical reagents to conciliate peptide bonding was performed for the first time 50 years ago. Chemical synthesis of AMPs can be performed in two ways: synthesis in a solution and solid-phase peptide synthesis (SPPS). Synthesis in a solution is implemented by dissolving all the components in the solution [43]. While in SPPS, an insoluble solid is attached to a $\mathrm{N}-\alpha$-derivative of an amino acid through a linker. Then the protecting group ( $\mathrm{N}-\alpha$ group) is removed, followed by washing the complex with the solvent. Coupling of the second amino acid (containing $\mathrm{N}-\alpha$ group) to the complex, 
either in the presence of activator or as a preactivated species, takes place. A solvent is used to wash the oligopeptide-linker-support complex, and unreacted matter is discarded. Repetition of withdrawing the protection group and the coupling cycle is performed until the required sequence of amino acids is achieved. Using the cleavage agent, peptide is generated in the form of free acid or amide (Figure 4) [44].

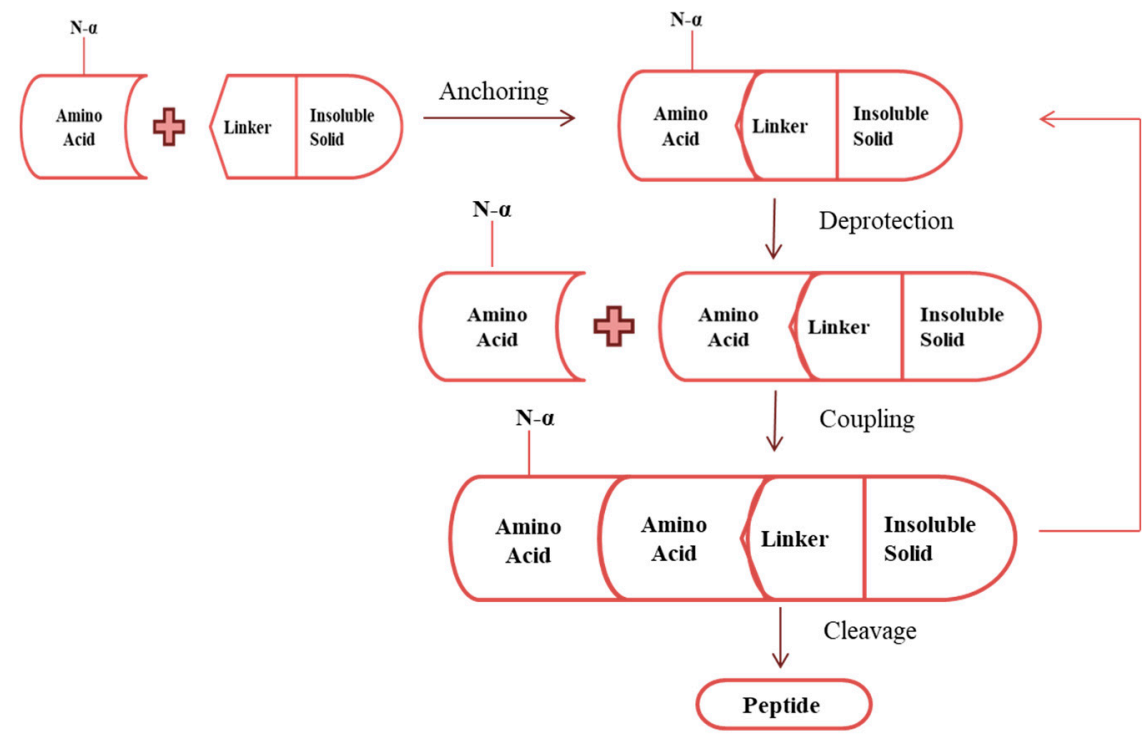

Figure 4. A representation of chemical synthesis of peptides via SPPS.

\subsection{Enzymatic Synthesis Mechanism}

Enzymatic synthesis of peptides uses enzymes, such as pepsin, papain, trypsin and others, to conciliate a peptide bond. Enzymatic synthesis is better than chemical synthesis as it can be used to manufacture small peptides ( $2-5$ oligomers), but it has a drawback that it is ineffective in the synthesis of long sequences [45]. It can be implemented in two ways: (i) reverse hydrolysis, which involves reversibility principle under the conditions that equilibrium is deliberately shifted towards peptide formation (Figure 5), and (ii) transpeptidation, which involves breaking the peptide bond and forming an active acyl-enzyme intermediate that further results in peptide formation in the presence of nucleophile (Figure 5) [40,46,47].

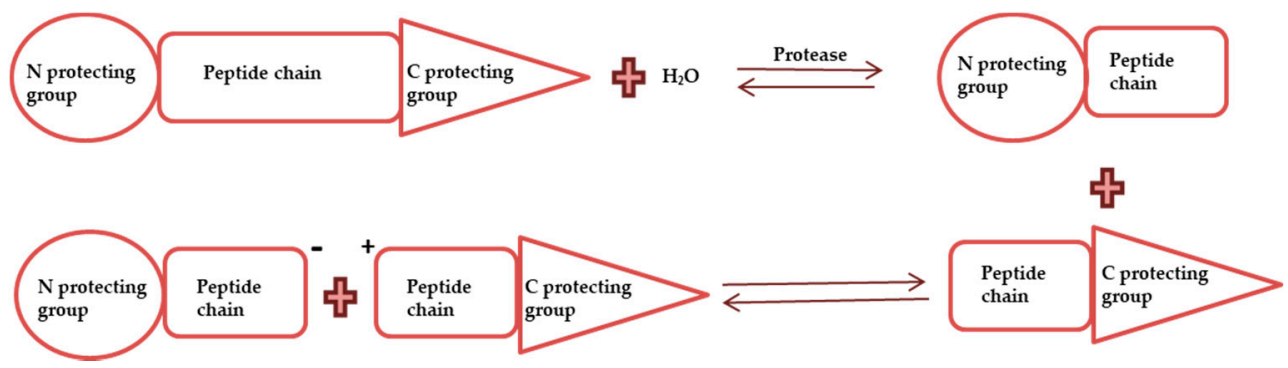

Figure 5. A representation of enzymatic synthesis of peptide using reverse hydrolysis.

\subsection{Synthesis Using Recombinant DNA Technology}

This mechanism involves cloning and gene expression, which produces a recombinant peptide, and E.coli is considered the most common host [48]. Synthesis of peptides using recombinant technology is considered the most economical method for massive production [49]. 


\section{Harvesting of Antimicrobial Peptides from Hermetia illucens}

Hermetia illucens are present ubiquitously, and since it survives in highly contaminated environment, it is capable of producing a huge spectrum of antimicrobial peptides. H. illucens consume cheaper feed and also grow faster, which is a highly recommended attribute for AMP isolation [50,51]. Defensins, cecropin, attacin and lysosymes are considered as representative antimicrobial peptides of $H$. illucens [10]. The mechanism of harvesting AMP from insects involves some important fundamentals, as discussed below. General steps in AMP harvesting are mentioned in the flow chart (Figure 6).

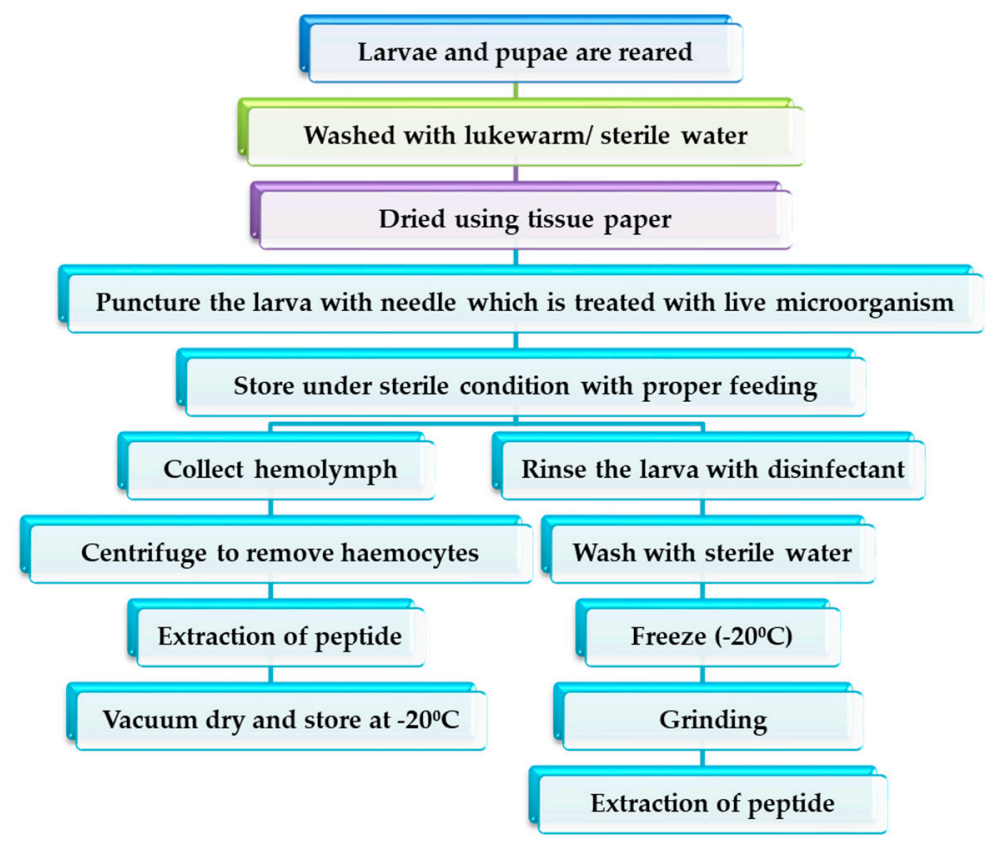

Figure 6. The general methodology for harvesting of AMP from H. illucens.

1. Larva collection and rearing:

In the process of insect formation from larva, several growth and development stages occur, which are usually known as instar. There is no specification for considering any specific instar larva for the AMP collection. However, in a study, the lowest transcription level was observed during first-instar larval stages and the highest transcription level during the fifth-instar larval stage [52]. At the fifth stage, growth is completed, and metamorphosis is initiated [53]. Therefore, considering fifth-instar larva will be beneficial in a higher rate of synthesis of peptides. If the larva is to be used as a feed, prepupa is better than larva because of its high chitin content [54]. Rearing of larva varies from study to study, depending on the criteria of the research. In an investigation, researchers observed that aqueous extracts of black soldier fly larvae fed a cellulose diet and protein-rich diet showed antimicrobial activity against Gram-negative bacteria, while larvae fed chitin, cellulose, bacteria and plant oil had higher inhibitory activity against Gram-positive bacteria [33]. Chloroform extract of larva showed the highest inhibitory activity when fed lignin, bacteria and plant oil diets. In contrast, in a report by [55], larvae were starved after inoculating the Lactobacillus sp. to study the antimicrobial activity of H. illucens extract. At the industrial level, cottonseed press cake is a good choice as feed for H. illucens due to its sustainability and cheaper cost [56].

2. Incorporation of microorganism into larvae:

Microorganisms are injected into the body of a larva or haemolymph using a needle. Inoculated microorganisms should be in the stationary phase because natural microbial infection in insects occurs in the stationary phase [12]. The microorganism is injected either to isolate and analyse the characteristics of the AMP formed for that specific microorganism 
or to examine the influence of immunisation on the antimicrobial activity towards different microorganisms. Several reports have claimed the antimicrobial activity of AMPs harvested from $H$. illucens, among which a few are mentioned in Table 3. In a study, AMPs from $H$. illucens were purified and investigated. AMPs were harvested from three samples: larvae that were immunised during the last instar stage, unimmunised larvae and mutilated larvae. From all the samples, haemolymph was collected and tested against E.coli and methicillin-resistant Staphylococcus aureus. Among all the samples, larvae that were immunised during the last instar stage showed the highest antimicrobial activity, while the mutilated group showed the least [51]. Zdybicka-Barabas observed that M. luteusimmunised haemolymph of $H$. illucens larvae showed inhibitory activity against Grampositive bacteria, whereas E.coli-immunised larvae showed activity against Gram-positive and Gram-negative bacteria. Additionally, it was concluded that synthesis of AMPs vary depending on the bacteria used for the immune challenge [57]. Usually, when AMPs are treated with enzymes, such as trypsin or chymotrypsin, it results in a loss of antimicrobial activity. However, when $H$. illucens are immunised with L. casei and given the same treatment, they remain unaffected [55].

Table 3. Antimicrobial activity of peptides extracted from H. illucens.

\begin{tabular}{|c|c|c|c|c|c|}
\hline S.No. & Source & Peptide & Harvesting Technique & $\begin{array}{l}\text { Microorganisms } \\
\text { Inhibited }\end{array}$ & References \\
\hline 1. & Haemolymph & \multirow{4}{*}{ stomoxynZH1 } & Solid phase extraction & Helicobacter pylori & [58] \\
\hline 2. & Crushed larva & & $\begin{array}{l}\text { RNA extraction } \\
\text { using Trizol }\end{array}$ & $\begin{array}{l}\text { S. aureus, E. coli, } \\
\text { Rhizoctonia solani and } \\
\text { Sclerotinia sclerotiorum }\end{array}$ & [59] \\
\hline 3. & Grounded larvae & & Maceration & $\begin{array}{l}\text { E. coli, P. fluorescens, } M \text {. } \\
\text { luteus and B. subtilis }\end{array}$ & [32] \\
\hline 4. & Larvae & & $\begin{array}{l}\text { Directly used as feed } \\
\text { for piglets }\end{array}$ & Lactobacilli, D-streptococci & {$[60]$} \\
\hline 5. & Lyophilized larvae & \multirow{3}{*}{$\begin{array}{l}\text { cecropin-like } \\
\text { peptide } 1\end{array}$} & $\begin{array}{l}\text { Homogenised and } \\
\text { extracted with } \\
\text { acidic methanol }\end{array}$ & $\begin{array}{l}\text { Methicillin resistant } \\
\text { Staphylococcus aureus }\end{array}$ & {$[61]$} \\
\hline 6. & Haemolymph & & $\begin{array}{l}\text { Solid-phase extraction } \\
\text { and reverse-phase } \\
\text { chromatography }\end{array}$ & $\begin{array}{c}\text { E. coli, Enterobacter } \\
\text { aerogens and } \\
\text { Pseudomonas areuginosa }\end{array}$ & [62] \\
\hline 7. & Grounded larva & & $\begin{array}{c}\text { Maceration } \\
\text { using methanol }\end{array}$ & Salmonella and E. coli & {$[63]$} \\
\hline 8. & $\begin{array}{c}\text { Larvae whose digestive } \\
\text { tract was removed. } \\
\text { Followed by treating } \\
\text { with liquid nitrogen }\end{array}$ & $\begin{array}{l}\text { Hidefensin-1, } \\
\text { Hidiptericin-1 } \\
\text { and HiCG13551 }\end{array}$ & $\begin{array}{l}\text { TRIeasy- RNA } \\
\text { isolation kit }\end{array}$ & $\begin{array}{c}\text { Streptococcus pneumonia, } \\
\text { E. coli and } \\
\text { Staphylococcus aureus }\end{array}$ & {$[64]$} \\
\hline
\end{tabular}

3. Storage conditions:

After the inoculation of the microorganism, the larvae are incubated under desired conditions. Storage conditions include temperature, humidity and time duration. The slight modification in haemostasis of a living entity can enhance its resistivity against stressors [65]. When homothermic animals are infected by a microorganism, their body temperature increases to reduce the microbial development and stimulate the immune response of the infected host. While insects are Poikilothermic animals, which are incapable of increasing their body temperature when infected, they move to a place with a higher temperature. Additionally, it has been reported that heat shock enhances the metabolism and speeds up the synthesis of defence molecules [66]. Hence, it can be recommended to store the treated larvae at a higher temperature to obtain better results in AMP harvesting.

4. Sample collection:

For AMP extraction from larvae, either haemolymph is collected, or the whole larva body is utilised. Hetru and Bulet collected the haemolymph in a precooled tube consisting 
of protease and melanisation inhibitors. Additionally, for small-sized insects, they froze the insects using liquid nitrogen, followed by grinding. Then, the powder was placed in water acidified with trifluoroacetic acid embodied with protease and melanisation inhibitor, followed by centrifugation and filtration [67]. Similarly, in most of the research, it was found that haemolymph is collected in ice-cold tubes consisting of phenylthiourea crystals to avoid coagulation. After collection, haemolymph is centrifuged to remove haemocytes [51]. Tabunoki proposed a method for collecting haemolymph from larva using a collection tube. This tube was prepared by making a hole at the bottom of a $0.5-\mathrm{mL}$ centrifuge tube and then placing this tube in a $1.5 \mathrm{~mL}$ tube [68]. Samples were collected from grounded larvae in a solution of methanol, water and acetic acid for characterisation. Additionally, the method to isolate RNA was considered as follows: dissect larvae in ice-cold PBS, soak foregut/ midgut, hindgut and salivary glands in lysis buffer, and then freeze [32]. Another protocol was reported in which larvae were ground and suspended in $20 \%$ acetic acid solution, followed by boiling and then centrifugation [55].

5. Purification of isolated samples from collected sample:

The next step after collecting the sample is purification using either of the techniques: solid-phase extraction, reversed-phase HPLC, size exclusion HPLC and enzymatic cleavage. The purpose of purification is to remove residual salts, synthesis reagents, partially deblocked peptides and truncated peptides [69]. Purified peptides are analysed for further study using mass spectrometry or sequencing [61].

6. Storage:

Haemolymph is stored at a freezing temperature until purified to maintain the stability. However, peptides are recommended to be utilised for analysis immediately after purification in order to prevent undesirable changes.

\section{Applications of Antimicrobial Peptides in Active Packaging}

Food packaging is a phenomenon of holding food in a material that fulfils four basic functions: containment, convenience, communication and protection. Containment refers to the fact that packaging material should be compatible with the food in terms of holding/carrying the product. Convenience means that the packaging material should be easy to use by the consumers. Communication means that the packaging material should include all the mandatory information required to be known to the consumer. Additionally, protection focuses on the prevention of undesirable changes in the physical, chemical and biological attributes of the food. Packaging can be classified based on the type of material, type of use and novel packaging. Based on the material packaging, there are four types: paper and paperboard, plastic, metal and glass. Based on usage, packaging has three types: primary, secondary and tertiary. Novel packaging includes innovative packaging, such as active packaging and intelligent packaging. Active packaging is defined as a packaging system that interacts with the surroundings of food to extend its shelf life [70]. Active packaging helps in achieving the selective permeation. Methods to incorporate active components into the packaging are coating, micro perforation, lamination, co-extrusion, or polymer blending [71]. Active packaging includes oxygen scavenger, carbon dioxide scavenger and emitters, ethylene scavenger, antimicrobial packaging and antioxidant packaging. Intelligent packaging provides information about the packaged product by sensing some of the properties of food, it includes indicators, sensors and data carriers [72]. In recent years, active packaging has attained a lot of attention due its capability to fulfil consumers demand as well as its positive impact towards biodegradability and sustainability.

Antimicrobial packaging is one type of active packaging, which can be defined as a system that prevents undesirable microbial growth on food, resulting in the deterioration of quality using antimicrobials, such as enzymes, bacteriocins, natural extracts, organic acids, etc. [73]. In the past few years, peptides harvested from insects have been investigated as antimicrobial agents for food packaging, and positive results were observed. The matrix used for carrying antimicrobial agents are usually bio-based polymers that can be 
biodegradable (for example, starch) or non-biodegradable (for example, polyethylene) to obtain a material with a negligible impact on environment [74]. These materials can be further classified into edible or non-edible, depending on the composition. Edible polymers, such as polysaccharides, proteins and lipids, have no hazardous impact on animals and humans [75]. The mechanism of antimicrobial packaging can be explained well by understanding the following three inter-related segments (Figure 7): (i) the incorporation system, (ii) the release system and (iii) the interaction and inhibition system.
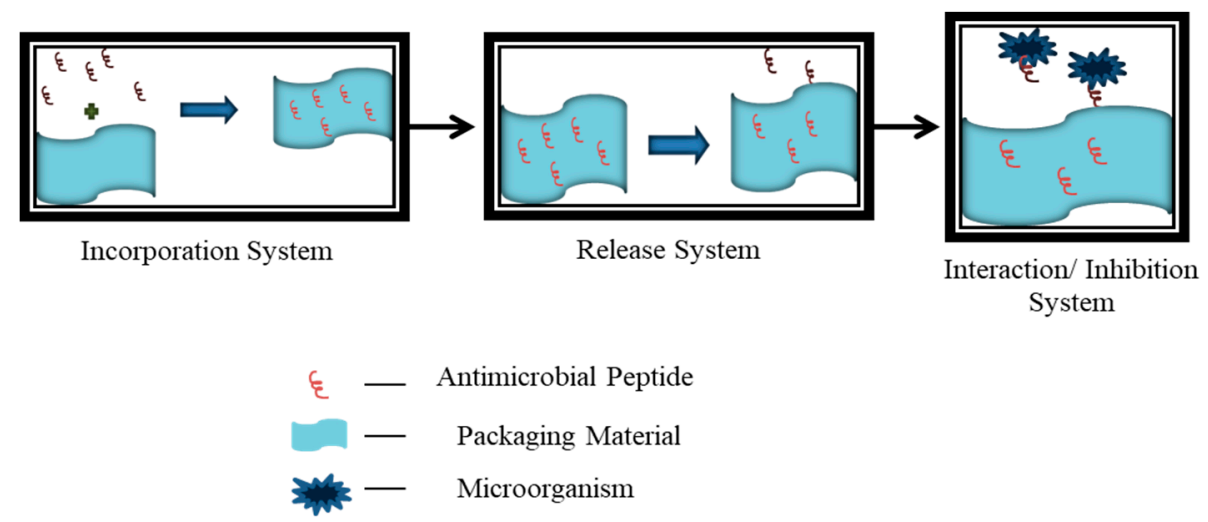

Figure 7. The basic mechanism of the antimicrobial peptide packaging system.

(i) The Incorporation System: This segment involves the study of the adequate addition of antimicrobial peptides into the packaging material. It includes the importance of the amount incorporated and the method of incorporation. Antimicrobial peptides can be incorporated into packaging material in three ways by directly incorporating peptides into packaging material, coating and immobilisation of peptides on the polymer surface using physical or chemical methods [50]. Precise incorporation system helps in attaining the stability and sustainability.

(ii) The Release System: Incorporated antimicrobial peptides are diffused from the packaging surface into the headspace or onto the food surface. The release of AMPs depends on temperature. When increasing the temperature, the release rate is found to increase. It was also reported that the type of packaging matrix affects the release rate of nisin. The highest nisin diffusion coefficient was observed in hydroxypropyl methylcellulose and the lowest in chitosan [76]. Gemili concluded that the porosity of the packaging material affects the release rate of antimicrobial agents [77]. Increasing the thickness reduces the release rate [78]. A slow release of the antimicrobial agent is a challenging aspect, but nanoencapsulation is found to be effective in speeding up the release [79]. Huang also suggested that micro-capsulation and nanofibres are useful in achieving controlled release rate [80].

(iii) The Interaction and Inhibition System: The released antimicrobial peptides interact with the headspace or food surface to destruct or inhibit the microbial growth. Initially, AMPs interact with the microbial cell membrane through electrostatic attraction, followed by killing the microbial cell [81]. Inhibitory and destructive activities of AMPs are previously discussed in Section 3 of this review.

There are several pieces of research based on the incorporation of AMPs derived from different sources other than insects into food packaging material. For example, the shelf-life extension of ham was reported in an investigation in which alginate films were impregnated with enterocins A and B. Enterocins A and B inhibited the growth of L. monocytogens in ham during storage [82]. Agrillo studied the incorporation of peptide 1018K6 into PET using cold plasma technology. Additionally, the results showed a reduction in the aerobic plate count, yeast and mould when the mozzarella cheese samples were packed in treated PET and stored under real conditions [83]. The incorporation of Lactobacillus curvatus into LLDPE via a coating was studied and showed the inhibitory activity against the Listeria species and Lactobacillus plantrum with no negative effect on the mechanical strength 
of film [84]. A highly effective bioactive PET film was developed by Gogliettino and her colleagues using mitochondrial-targeted peptide 1 (MTP1). This film was prepared by treating the PET surface with plasma to increase the wettability of the film, followed by incubating the film in $50 \mu \mathrm{m}$ (MTP1) of solution for $24 \mathrm{~h}$ at $25^{\circ} \mathrm{C}$. Due to the plasma treatment, wettability was reduced from $89^{\circ}$ to $76^{\circ}$, and in addition of MET1, it further decreased to $36^{\circ}$; hence, hydrophilicity is increased. For a shelf-life study on buffalo meat, $50 \mathrm{~g}$ from sirloin steaks were placed along with MTP1-functionlised film disk with a $9 \mathrm{~cm}$ diameter. Un-functionalised films were considered as control. The shelf life of buffalo meat was enhanced up to 6 days when placed with functionalised film, whereas control reached beyond the acceptability microbial count $(7 \mathrm{Log} \mathrm{CFU} / \mathrm{g}$ ) on the fourth day of storage. For a shelf-life enhancement analysis of ricotta cheese, $30 \mathrm{~g}$ of ricotta cheese was placed along with $2.5 \mathrm{~cm}$ of MTP1-functionlised disk, and untreated PET films were considered as control. From the shelf-life study on ricotta cheese, it was observed that samples with functionalised film stayed fresh up to 10 days, while control samples spoiled after the fourth day [85]. It can be concluded from these studies that AMPs have a future scope in the food packaging industry.

\subsection{Future Scope of AMP Derived from Insects in Food Packaging}

The incorporation of AMPs harvested from insects into packaging material could be helpful in preventing food deterioration. Defensis has antimicrobial activity against Staphyloccocus aureus, which is one of the commonly found pathogenic microorganisms in food, such as meat products and dairy products [86]. Cecropins B and cercopin P1 have shown inhibitory activity against $E$. coli $[87,88]$ which is found in milk, meat and raw vegetables. Inhibitory activity of attacin against Gram-negative bacteria was observed in research [89]. Drosocin has shown resistivity against M. Luteus, which is found in milk and goat's cheese [90]. Antimicrobial activity of diptericins against E. coli K12, Erwinia hericola $\mathrm{T}$ and Erwinia carotovora 113 was observed [91]. Erwinia sp. is usually found on tomato fruit causing bacterial soft rot [92]. Metchnokwin inhibits growth of fungi and Gram-positive bacteria [93]. Bacterial disease of rice can be inhibited using melittin [94]. The antimicrobial activity of persulcatusin against MRSA (methicillin-sensitive S. aureus) is highest among all AMPs [95]. MRSA is one of the major causes of infections that are usually present in animal-originated foods $[96,97]$. Minimally processed foods, such as cold-pressed non-alcoholic apple cider, milk, raw meat and mixed salad leaves, are the vehicles for the transmission of Cryptosporidium parvum, which can be inhibited by Pyrrhocoricin $[98,99]$. Studies focused on impregnation of such peptide isolated from the insects into the packaging matrix have great potential towards reducing food deterioration due to microbial contamination.

\subsection{Challenges in Incorporation of AMP into Food Packaging Material}

The incorporation of antimicrobial peptides into the packaging material has several challenges when it has to be commercialised. Some of the main issues are discussed further:

(i) Compatibility between the packaging matrix and AMP: The impregnation of AMP into packaging material requires a certain level of compatibility to prevent the destruction of the AMP and ensure proper binding to the packaging material. Direct incorporation of antimicrobial compounds affects the release rate and durability [100]. Li reported that covalent bonding between the antimicrobial peptide and packaging matrix helps to counterblast the release but has a negative impact on the stability of the antimicrobial activity's efficiency [101].

(ii) Compatibility between AMP-impregnated package and food: This factor can be assessed by migration tests and extraction experiments [102,103]. It should be ensured that AMP-impregnated material does not release any toxic or undesirable compounds due to chemical reactions.

(iii) Stability on treatment: Packaging material has to undergo several high-temperature and pressure treatments. Additionally, in some cases, after the placement of the food inside 
the packaging, it is passed through preservation treatments, such as UHT, aseptic packaging and modified atmosphere packaging. Therefore, AMP should be capable of resisting changes during such treatments. High-temperature treatments during thermal-mechanical transformation processes reduce the antimicrobial activity of the packaging material [104]

(iv) Release System: Once the AMP is introduced into the packaging material, it has to have a controlled release rate throughout the expiry of the food product to ensure the food safety, which is quite challenging. Crystalline regions create difficulty in releasing compounds (or AMPs) from packaging matrix [100].

(v) Complications during harvesting and its production cost: Techniques known for harvesting AMPs are tedious, which makes it difficult to be performed at a large scale. The production cost of AMPs needs to be reduced with improved production efficiency. Sierra an Viñas, in an extensive review of peptide development, claimed that synthesis of high-molecular-weight AMPs is complicated, has lesser yield and a higher production rate [105].

\section{Conclusions}

Food packaging incorporated with active components is attaining focus of researchers due to its appreciable results and scope. Usually, the main cause of food spoilage is found to be microbial contamination. The prevention of microbial contamination can be performed by either injecting additives directly into the food or into the packaging material. Among these two methods, the direct incorporation into food may result in changes in the chemical composition of the food, customer's dissatisfaction due to perception and health issues if consumed more than the recommended amount by standards. While impregnated packaging material is only responsible for releasing active components into the headspace or on the food surface. This active component can have antimicrobial activity, antioxidant activity, ethylene scavengers or any other mechanisms of action as per the requirement of the food to be preserved. This investigation emphasises the activity of peptides as an antimicrobial agent in food packaging.

In this study, we reported the synthesis and harvesting of antimicrobial peptides from insects, specifically from Hermetia illucens. H. illucens is one of the highly recommended sources for AMP harvesting because of its easy availability and wide range of immune responses. This report includes discussion on peptides that can be incorporated into food packaging material to inhibit microbial growth and to enhance the shelf life of food. Various scientific data are available to prove the capability of AMPs incorporated into food packaging for quality preservation. Recent investigations suggest that the incorporation of AMPs into packaging material has several shortcomings, which can be encountered with some modifications. AMPs in food packaging material have potential in preservation either by interacting with the headspace or in direct contact with the food.

Author Contributions: A.S. carried out the literature search, analysed and wrote the manuscript. H.L. commented and edited the manuscript. S.R. supervised the project and provided scope and directions. All authors have read and agreed to the published version of the manuscript.

Funding: No research grant received for this work. There is no external funding source for APC charges.

Institutional Review Board Statement: No human or animal subjects involved. Hence IRB is not necessary.

Conflicts of Interest: The authors declare no conflict of interest.

\section{References}

1. Martin, S.F. Adaptation in the innate immune system and heterologous innate immunity. Cell. Mol. life Sci. 2014, 71, 4115-4130. [CrossRef] [PubMed]

2. Sirtori, L.R.; Motta, A.D.; Brandelli, A. Mode of action of antimicrobial peptide P45 on Listeria monocytogenes. J. Basic Microbiol. 2008, 48, 393-400. [CrossRef] [PubMed] 
3. Chung, P.Y.; Khanum, R. Antimicrobial peptides as potential anti-biofilm agents against multidrug-resistant bacteria. J. Microbiol. Immunol. Infect. 2017, 50, 405-410. [CrossRef]

4. Mahlapuu, M.; Håkansson, J.; Ringstad, L.; Björn, C. Antimicrobial peptides: An emerging category of therapeutic agents. Front. Cell. Infect. Microbiol. 2016, 6, 194. [CrossRef]

5. Fjell, C.D.; Hiss, J.A.; Hancock, R.E.; Schneider, G. Designing antimicrobial peptides: Form follows function. Nat. Rev. Drug Discov. 2012, 11, 37-51. [CrossRef]

6. Tonk, M.; Vilcinskas, A.; Rahnamaeian, M. Insect antimicrobial peptides: Potential tools for the prevention of skin cancer. Appl. Microbiol. Biotechnol. 2016, 100, 7397-7405. [CrossRef] [PubMed]

7. Patocka, J.; Nepovimova, E.; Klimova, B.; Wu, Q.; Kuca, K. Antimicrobial peptides: Amphibian host defense peptides. Curr. Med. Chem. 2019, 26, 5924-5946. [CrossRef] [PubMed]

8. Sun, J.; Furio, L.; Mecheri, R.; van der Does, A.M.; Lundeberg, E.; Saveanu, L.; Chen, Y.; van Endert, P.; Agerberth, B.; Diana, J. Pancreatic $\beta$-cells limit autoimmune diabetes via an immunoregulatory antimicrobial peptide expressed under the influence of the gut microbiota. Immunity 2015, 43, 304-317. [CrossRef]

9. Hillyer, J.F. Insect immunology and hematopoiesis. Dev. Comp. Immunol. 2016, 58, 102-118. [CrossRef]

10. Moretta, A.; Salvia, R.; Scieuzo, C.; Di Somma, A.; Vogel, H.; Pucci, P.; Sgambato, A.; Wolff, M.; Falabella, P. A bioinformatic study of antimicrobial peptides identified in the Black Soldier Fly (BSF) Hermetia illucens (Diptera: Stratiomyidae). Sci. Rep. 2020, 10, 1-4. [CrossRef] [PubMed]

11. Lee, K.S.; Yun, E.Y.; Goo, T.W. Antimicrobial activity of an extract of Hermetia illucens larvae immunized with Lactobacillus casei against Salmonella species. Insects 2020, 11, 704. [CrossRef] [PubMed]

12. Haine, E.R.; Moret, Y.; Siva-Jothy, M.T.; Rolff, J. Antimicrobial defense and persistent infection in insects. Science 2008, 322, 1257-1259. [CrossRef] [PubMed]

13. Hultmark, D.; Steiner, H.; Rasmuson, T.; Boman, H.G.; Insect immunity. Purification and properties of three inducible bactericidal proteins from hemolymph of immunized pupae of Hyalophora cecropia. Eur. J. Biochem. 1980, 106, 7-16. [CrossRef]

14. Steiner, H.; Hultmark, D.; Engström, Å.; Bennich, H.; Boman, H.G. Sequence and specificity of two antibacterial proteins involved in insect immunity. Nature 1981, 292, 246-248. [CrossRef] [PubMed]

15. Thomas, S.; Karnik, S.; Barai, R.S.; Jayaraman, V.K.; Idicula-Thomas, S. CAMP: A useful resource for research on antimicrobial peptides. Nucleic Acids Res. 2010, 38 (Suppl. 1), D774-D780. [CrossRef]

16. Santos, J.C.; Sousa, R.C.; Otoni, C.G.; Moraes, A.R.; Souza, V.G.; Medeiros, E.A.; Espitia, P.J.; Pires, A.C.; Coimbra, J.S.; Soares, N.F. Nisin and other antimicrobial peptides: Production, mechanisms of action, and application in active food packaging. Innov. Food Sci. Emerg. Technol. 2018, 48, 179-194. [CrossRef]

17. Malhotra, B.; Keshwani, A.; Kharkwal, H. Antimicrobial food packaging: Potential and pitfalls. Front. Microbiol. 2015,6 , 611. [CrossRef]

18. Lu, H.L.; Leger, R.S. Insect immunity to entomopathogenic fungi. Adv. Genet. 2016, 94, 251-285.

19. Scocchi, M.; Mardirossian, M.; Runti, G.; Benincasa, M. Non-membrane permeabilizing modes of action of antimicrobial peptides on bacteria. Curr. Top. Med. Chem. 2016, 16, 76-88. [CrossRef]

20. Reddy, K.V.; Yedery, R.D.; Aranha, C. Antimicrobial peptides: Premises and promises. Int. J. Antimicrob. Agents 2004, $24,536-547$. [CrossRef]

21. Jenssen, H.; Hamill, P.; Hancock, R.E. Peptide antimicrobial agents. Clin. Microbiol. Rev. 2006, 19, 491-511. [CrossRef]

22. De Lucca, A.J.; Walsh, T.J. Antifungal peptides: Novel therapeutic compounds against emerging pathogens. Antimicrob. Agents Chemother. 1999, 43, 1-11. [CrossRef]

23. Matanic, V.C.; Castilla, V. Antiviral activity of antimicrobial cationic peptides against Junin virus and herpes simplex virus. Int. J. Antimicrob. Agents 2004, 23, 382-389. [CrossRef]

24. Chia, T.J.; Wu, Y.C.; Chen, J.Y.; Chi, S.C. Antimicrobial peptides (AMP) with antiviral activity against fish nodavirus. Fish Shellfish. Immunol. 2010, 28, 434-439. [CrossRef]

25. Mohan, K.V.; Rao, S.S.; Atreya, C.D. Antiviral activity of selected antimicrobial peptides against vaccinia virus. Antivir. Res. 2010, 86, 306-311. [CrossRef] [PubMed]

26. Otvos, L., Jr. Antibacterial peptides isolated from insects. J. Pept. Sci. Off. Publ. Eur. Pept. Soc. 2000, 6, $497-511$.

27. Yaakobi, K.; Liebes-Peer, Y.; Kushmaro, A.; Rapaport, H. Designed amphiphilic $\beta$-sheet peptides as templates for paraoxon adsorption and detection. Langmuir 2013, 29, 6840-6848. [CrossRef]

28. Freudenthal, O.; Quilès, F.; Francius, G. Discrepancies between cyclic and linear antimicrobial peptide actions on the spectrochemical and nanomechanical fingerprints of a young biofilm. ACS Omega 2017, 2, 5861-5872. [CrossRef] [PubMed]

29. Moreno-Montoro, M.; Olalla-Herrera, M.; Rufián-Henares, J.Á.; Martínez, R.G.; Miralles, B.; Bergillos, T.; Navarro-Alarcón, M.; Jauregi, P. Antioxidant, ACE-inhibitory and antimicrobial activity of fermented goat milk: Activity and physicochemical property relationship of the peptide components. Food Funct. 2017, 8, 2783-2791. [CrossRef] [PubMed]

30. Epand, R.M.; Vogel, H.J. Diversity of antimicrobial peptides and their mechanisms of action. Biochim. Biophys. Acta (BBA)Biomembr. 1999, 1462, 11-28. [CrossRef]

31. Podda, E.; Benincasa, M.; Pacor, S.; Micali, F.; Mattiuzzo, M.; Gennaro, R.; Scocchi, M. Dual mode of action of Bac7, a proline-rich antibacterial peptide. Biochim. Biophys. Acta (BBA)-Gen. Subj. 2006, 1760, 1732-1740. [CrossRef] 
32. Makarova, O.; Johnston, P.; Rodriguez-Rojas, A.; El Shazely, B.; Morales, J.M.; Rolff, J. Genomics of experimental adaptation of Staphylococcus aureus to a natural combination of insect antimicrobial peptides. Sci. Rep. 2018, 8, 1-8. [CrossRef]

33. Vogel, H.; Müller, A.; Heckel, D.G.; Gutzeit, H.; Vilcinskas, A. Nutritional immunology: Diversification and diet-dependent expression of antimicrobial peptides in the black soldier fly Hermetia illucens. Dev. Comp. Immunol. 2018, 78, 141-148. [CrossRef]

34. Shin, H.S.; Park, S.I. Novel attacin from Hermetia illucens: cDNA cloning, characterization, and antibacterial properties. Prep. Biochem. Biotechnol. 2019, 49, 279-285. [CrossRef] [PubMed]

35. Wang, G. Improved methods for classification, prediction, and design of antimicrobial peptides. In Computational Peptidology; Humana Press: New York, NY, USA, 2015; pp. 43-66.

36. Lee, J.H.; Kim, I.W.; Kim, M.; Ahn, M.Y.; Yun, E.Y.; Hwang, J.S. Antimicrobial activity of the scolopendrasin V peptide identified from the centipede Scolopendra subspinipes mutilans. J. Microbiol. Biotechnol. 2017, 27, 43-48. [CrossRef]

37. Vizioli, J.; Salzet, M. Antimicrobial peptides from animals: Focus on invertebrates. Trends Pharmacol. Sci. 2002, 23, 494-496. [CrossRef]

38. Li, F.F.; Brimble, M.A. Using chemical synthesis to optimise antimicrobial peptides in the fight against antimicrobial resistance. Pure Appl. Chem. 2019, 91, 181-198. [CrossRef]

39. Guzmán, F.; Barberis, S.; Illanes, A. Peptide synthesis: Chemical or enzymatic. Electron. J. Biotechnol. 2007, 10, 279-314. [CrossRef]

40. Perez Espitia, P.J.; de Fátima Ferreira Soares, N.; dos Reis Coimbra, J.S.; de Andrade, N.J.; Souza Cruz, R.; Alves Medeiros, E.A. Bioactive peptides: Synthesis, properties, and applications in the packaging and preservation of food. Compr. Rev. Food Sci. Food Saf. 2012, 11, 187-204. [CrossRef] [PubMed]

41. Burrill, G.S. The biotechnology industry: An engine of innovation. In Biotechnology Entrepreneurship; Academic Press: Cambridge, MA, USA, 2014; pp. 21-44.

42. Cavaco, M.; Castanho, M.A.; Neves, V. Peptibodies: An elegant solution for a long-standing problem. Pept. Sci. 2018, 110, e23095. [CrossRef]

43. Kent, S.B. Chemical synthesis of peptides and proteins. Annu. Rev. Biochem. 1988, 57, 957-989. [CrossRef] [PubMed]

44. Borgia, J.A.; Fields, G.B. Chemical synthesis of proteins. Trends Biotechnol. 2000, 18, 243-251. [CrossRef]

45. So, J.E.; Kang, S.H.; Kim, B.G. Lipase-catalyzed synthesis of peptides containing D-amino acid. Enzym. Microb. Technol. 1998, 23, 211-215. [CrossRef]

46. Machado, A.; Liria, C.W.; Proti, P.B.; Remuzgo, C.; Miranda, M.T. Sínteses química e enzimática de peptídeos: Princípios básicos e aplicações. Química Nova 2004, 27, 781-789. [CrossRef]

47. Boeriu, C.G.; Frissen, A.E.; Boer, E.; van Kekem, K.; van Zoelen, D.J.; Eggen, I.F. Optimized enzymatic synthesis of C-terminal peptide amides using subtilisin A from Bacillus licheniformis. J. Mol. Catal. B Enzym. 2010, 66, 33-42. [CrossRef]

48. Wang, Q.; Zhu, F.; Xin, Y.; Liu, J.; Luo, L.; Yin, Z. Expression and purification of antimicrobial peptide buforin IIb in Escherichia coli. Biotechnol. Lett. 2011, 33, 2121-2126. [CrossRef] [PubMed]

49. Li, Y. Recombinant production of antimicrobial peptides in Escherichia coli: A review. Protein Expr. Purif. 2011, 80, 260-267. [CrossRef]

50. Choi, Y.C.; Park, K.H.; Nam, S.H.; Jang, B.G.; Kim, J.H.; Kim, D.W.; Yu, D.J. The effect on growth performance of chicken meat in broiler chicks by dietary supplementation of black soldier fly larvae, Hermetia illucens (Diptera: Stratmyidae). J. Sericultural Entomol. Sci. 2013, 51, 30-35. [CrossRef]

51. Park, S.I.; Kim, J.W.; Yoe, S.M. Purification and characterization of a novel antibacterial peptide from black soldier fly (Hermetia illucens) larvae. Dev. Comp. Immunol. 2015, 52, 98-106. [CrossRef]

52. Wang, Q.; Wang, J.; Ren, M.; Ma, S.; Liu, X.; Chen, K.; Xia, H. Peptidoglycan recognition protein-S1 acts as a receptor to activate AMP expression through the IMD pathway in the silkworm Bombyx mori. Dev. Comp. Immunol. 2021, 115, 103903. [CrossRef]

53. Nijhout, H.F. Physiological control of molting in insects. Am. Zool. 1981, 21, 631-640. [CrossRef]

54. Barragan-Fonseca, K.B.; Dicke, M.; van Loon, J.J. Nutritional value of the black soldier fly (Hermetia illucens L.) and its suitability as animal feed-a review. J. Insects Food Feed. 2017, 3, 105-120. [CrossRef]

55. Lee, K.S.; Yun, E.Y.; Goo, T.W. Evaluation of the Antimicrobial Activity of an Extract of Lactobacillus casei-Infected Hermetia illucens Larvae Produced Using an Automatic Injection System. Animals 2020, 10, 2121. [CrossRef]

56. Tegtmeier, D.; Hurka, S.; Klüber, P.; Brinkrolf, K.; Heise, P.; Vilcinskas, A. Cottonseed press cake as a potential diet for industrially farmed black soldier fly larvae triggers adaptations of their bacterial and fungal gut microbiota. Front. Microbiol. 2021, 12, 563. [CrossRef] [PubMed]

57. Zdybicka-Barabas, A.; Bulak, P.; Polakowski, C.; Bieganowski, A.; Waśko, A.; Cytryńska, M. Immune response in the larvae of the black soldier fly Hermetia illucens. Invertebr. Surviv. J. 2017, 14, 9-17.

58. Alvarez, D.; Wilkinson, K.A.; Treilhou, M.; Téné, N.; Castillo, D.; Sauvain, M. Prospecting peptides isolated from black soldier fly (Diptera: Stratiomyidae) with antimicrobial activity against Helicobacter pylori (Campylobacterales: Helicobacteraceae). J. Insect Sci. 2019, 19, 17. [CrossRef]

59. Elhag, O.; Zhou, D.; Song, Q.; Soomro, A.A.; Cai, M.; Zheng, L.; Yu, Z.; Zhang, J. Screening, expression, purification and functional characterization of novel antimicrobial peptide genes from Hermetia illucens (L.). PLoS ONE 2017, 12, e0169582. [CrossRef]

60. Spranghers, T.; Michiels, J.; Vrancx, J.; Ovyn, A.; Eeckhout, M.; De Clercq, P.; De Smet, S. Gut antimicrobial effects and nutritional value of black soldier fly (Hermetia illucens L.) prepupae for weaned piglets. Anim. Feed. Sci. Technol. 2018, 235, 33-42. [CrossRef] 
61. Park, S.I.; Chang, B.S.; Yoe, S.M. Detection of antimicrobial substances from larvae of the black soldier fly, H ermetia illucens (D iptera: S tratiomyidae). Entomol. Res. 2014, 44, 58-64. [CrossRef]

62. Park, S.I.; Yoe, S.M. A novel cecropin-like peptide from black soldier fly, Hermetia illucens: Isolation, structural and functional characterization. Entomol. Res. 2017, 47, 115-124. [CrossRef]

63. Harlystiarini, H.; Mutia, R.; Wibawan, I.W.; Astuti, D.A. In vitro antibacterial activity of black soldier fly (hermetia illucens) larva extracts against gram-negative bacteria. Bul. Peternak. 2019, 43. [CrossRef]

64. Xu, J.; Luo, X.; Fang, G.; Zhan, S.; Wu, J.; Wang, D.; Huang, Y. Transgenic expression of antimicrobial peptides from black soldier fly enhance resistance against entomopathogenic bacteria in the silkworm, Bombyx mori. Insect Biochem. Mol. Biol. 2020, 127, 103487. [CrossRef] [PubMed]

65. Mattson, M.P.; Calabrese, E.J. (Eds.) Hormesis: A Revolution in Biology, Toxicology and Medicine; Springer Science \& Business Media: Totowa, NJ, USA, 1 December 2009.

66. Wojda, I. Temperature stress and insect immunity. J. Therm. Biol. 2017, 68, 96-103. [CrossRef] [PubMed]

67. Hetru, C.; Bulet, P. Strategies for the isolation and characterization of antimicrobial peptides of invertebrates. In Antibacterial Peptide Protocols; Humana Press: Totowa, NJ, USA, 1997; pp. 35-49.

68. Tabunoki, H.; Dittmer, N.T.; Gorman, M.J.; Kanost, M.R. Development of a new method for collecting hemolymph and measuring phenoloxidase activity in Tribolium castaneum. BMC Res. Notes 2019, 12, 1-7. [CrossRef] [PubMed]

69. Stawikowski, M.; Fields, G.B. Introduction to peptide synthesis. Curr. Protoc. Protein Sci. 2012, 69, 18.1.1-18.1.13. [CrossRef] [PubMed]

70. Pereira de Abreu, D.A.; Cruz, J.M.; Paseiro Losada, P. Active and intelligent packaging for the food industry. Food Rev. Int. 2012, 28, 146-187. [CrossRef]

71. Kour, H.; Wani, N.A.; Malik, A.; Kaul, R.; Chauhan, H.; Gupta, P.; Bhat, A.; Singh, J. Advances in food packaging-A review. Stewart Postharvest Rev. 2013, 9, 1-7.

72. Nagarajarao, R.C. Recent advances in processing and packaging of fishery products: A review. Aquat. Procedia 2016, 7, 201-213. [CrossRef]

73. Corrales, M.; Fernández, A.; Han, J.H. Antimicrobial packaging systems. In Innovations in Food Packaging; Academic Press: Cambridge, MA, USA, 2014; pp. 133-170.

74. Babu, R.P.; O'connor, K.; Seeram, R. Current progress on bio-based polymers and their future trends. Prog. Biomater. 2013, 2, 1-6. [CrossRef]

75. Kouhi, M.; Prabhakaran, M.P.; Ramakrishna, S. Edible polymers: An insight into its application in food, biomedicine and cosmetics. Trends Food Sci. Technol. 2020, 103, 248-263. [CrossRef]

76. Marvdashti, L.M.; Yavarmanesh, M.; Koocheki, A. Controlled release of nisin from polyvinyl alcohol-Alyssum homolocarpum seed gum composite films: Nisin kinetics. Food Biosci. 2019, 28, 133-139. [CrossRef]

77. Gemili, S.; Yemenicioğlu, A.; Altınkaya, S.A. Development of cellulose acetate based antimicrobial food packaging materials for controlled release of lysozyme. J. Food Eng. 2009, 90, 453-462. [CrossRef]

78. Seo, H.S.; Bang, J.; Kim, H.; Beuchat, L.R.; Cho, S.Y.; Ryu, J.H. Development of an antimicrobial sachet containing encapsulated allyl isothiocyanate to inactivate Escherichia coli O157: H7 on spinach leaves. Int. J. Food Microbiol. 2012, 159, 136-143. [CrossRef] [PubMed]

79. Bahrami, A.; Delshadi, R.; Assadpour, E.; Jafari, S.M.; Williams, L. Antimicrobial-loaded nanocarriers for food packaging applications. Adv. Colloid Interface Sci. 2020, 278, 102140. [CrossRef]

80. Huang, T.; Qian, Y.; Wei, J.; Zhou, C. Polymeric antimicrobial food packaging and its applications. Polymers 2019, 11, 560. [CrossRef]

81. Lee, T.H.; NHall, K.; Aguilar, M.I. Antimicrobial peptide structure and mechanism of action: A focus on the role of membrane structure. Curr. Top. Med. Chem. 2016, 16, 25-39. [CrossRef] [PubMed]

82. Marcos, B.; Aymerich, T.; Monfort, J.M.; Garriga, M. High-pressure processing and antimicrobial biodegradable packaging to control Listeria monocytogenes during storage of cooked ham. Food Microbiol. 2008, 25, 177-182. [CrossRef]

83. Agrillo, B.; Balestrieri, M.; Gogliettino, M.; Palmieri, G.; Moretta, R.; Proroga, Y.T.; Rea, I.; Cornacchia, A.; Capuano, F.; Smaldone, G.; et al. Functionalized polymeric materials with bio-derived antimicrobial peptides for "active" packaging. Int. J. Mol. Sci. 2019, 20, 601. [CrossRef]

84. Blanco Massani, M.; Fernandez, M.R.; Ariosti, A.; Eisenberg, P.; Vignolo, G. Development and characterization of an active polyethylene film containing Lactobacillus curvatus CRL705 bacteriocins. Food Addit. Contam. 2008, 25, 1424-1430. [CrossRef]

85. Gogliettino, M.; Balestrieri, M.; Ambrosio, R.L.; Anastasio, A.; Smaldone, G.; Proroga, Y.T.; Moretta, R.; Rea, I.; De Stefano, L.; Agrillo, B.; et al. Extending the shelf-life of meat and dairy products via PET-modified packaging activated with the antimicrobial peptide MTP1. Front. Microbiol. 2020, 10, 2963. [CrossRef]

86. Gomes, P.D.; Fernandes, M.H. Defensins in the oral cavity: Distribution and biological role. J. Oral Pathol. Med. 2010, 39, 1-9. [CrossRef]

87. Giacometti, A.; Cirioni, O.; Ghiselli, R.; Viticchi, C.; Mocchegiani, F.; Riva, A.; Saba, V.; Scalise, G. Effect of mono-dose intraperitoneal cecropins in experimental septic shock. Crit. Care Med. 2001, 29, 1666-1669. [CrossRef]

88. Hou, Z.; Wang, W.; Liu, Z.; Liu, G.; Souffrant, W.B.; Yin, Y. Effect of lactoferrincin B and cecropin P1 against enterotoxigenic Escherichia coli in vitro. J. Food Agric. Environ. 2011, 9, 271-274. 
89. Carlsson, A.; Nyström, T.; de Cock, H.; Bennich, H. Attacin-an insect immune protein-binds LPS and triggers the specific inhibition of bacterial outer-membrane protein synthesis. Microbiology 1998, 144, 2179-2188. [CrossRef] [PubMed]

90. Bulet, P.; Dimarcq, J.L.; Hetru, C.; Lagueux, M.; Charlet, M.; Hegy, G.; Van Dorsselaer, A.; Hoffmann, J.A. A novel inducible antibacterial peptide of Drosophila carries an O-glycosylated substitution. J. Biol. Chem. 1993, 268, 14893-14897. [CrossRef]

91. Keppi, E.; Pugsley, A.P.; Lambert, J.; Wicker, C.; Dimarcq, J.L.; Hoffmann, J.A.; Hoffmann, D. Mode of action of diptericin A, a bactericidal peptide induced in the hemolymph of Phormia terranovae larvae. Arch. Insect Biochem. Physiol. 1989, 10, $229-239$. [CrossRef]

92. Blancard, D.; Laterrot, H.; Marchoux, G.; Candresse, T. 2-Diagnosis of parasitic and nonparasitic diseases. Tomato Dis. 2012, 35-411. [CrossRef]

93. Levashina, E.A.; Ohresser, S.; Bulet, P.; Reichhart, J.M.; Hetru, C.; Hoffmann, J.A. Metchnikowin, a novel immune-inducible proline-rich peptide from Drosophila with antibacterial and antifungal properties. Eur. J. Biochem. 1995, 233, 694-700. [CrossRef]

94. Shi, W.; Li, C.; Li, M.; Zong, X.; Han, D.; Chen, Y. Antimicrobial peptide melittin against Xanthomonas oryzae pv. oryzae, the bacterial leaf blight pathogen in rice. Appl. Microbiol. Biotechnol. 2016, 100, 5059-5067. [CrossRef] [PubMed]

95. Miyoshi, N.; Saito, T.; Ohmura, T.; Kuroda, K.; Suita, K.; Ihara, K.; Isogai, E. Functional structure and antimicrobial activity of persulcatusin, an antimicrobial peptide from the hard tick Ixodes persulcatus. Parasites Vectors 2016, 9, 1-11. [CrossRef]

96. da Silva, A.C.; Rodrigues, M.X.; Silva, N.C. Methicillin-resistant Staphylococcus aureus in food and the prevalence in Brazil: A review. Braz. J. Microbiol. 2020, 51, 347-356. [CrossRef] [PubMed]

97. Sergelidis, D.; Angelidis, A.S. Methicillin-resistant Staphylococcus aureus: A controversial food-borne pathogen. Lett. Appl. Microbiol. 2017, 64, 409-418. [CrossRef] [PubMed]

98. Ahmed, S.A.; Karanis, P. An overview of methods/techniques for the detection of Cryptosporidium in food samples. Parasitol. Res. 2018, 117, 629-653. [CrossRef]

99. Boxell, A.; Lee, S.H.; Jefferies, R.; Watt, P.; Hopkins, R.; Reid, S.; Armson, A.; Ryan, U. Pyrrhocoricin as a potential drug delivery vehicle for Cryptosporidium parvum. Exp. Parasitol. 2008, 119, 301-303. [CrossRef] [PubMed]

100. Khaneghah, A.M.; Hashemi, S.M.; Limbo, S. Antimicrobial agents and packaging systems in antimicrobial active food packaging: An overview of approaches and interactions. Food Bioprod. Process. 2018, 111, 1-9. [CrossRef]

101. Li, K.; Chen, J.; Xue, Y.; Ding, T.; Zhu, S.; Mao, M.; Zhang, L.; Han, Y. Polymer brush grafted antimicrobial peptide on hydroxyapatite nanorods for highly effective antibacterial performance. Chem. Eng. J. 2021, 423, 130133. [CrossRef]

102. Ma, Y.N.; Ma, L.; Jiang, Y. Interpretation of the guideline of compatibility study of pharmaceutical products and packaging materials the assessment of experimental data. Chin. J. New Drugs 2014, 28, 940-943.

103. Qian, Q.J.; Zhao, X.J.; Ma, Q.H.; Jiang, J.M.; Wei, R.; Chen, G.; Fu, L.F. Study on compatibility in between packaging materials and Haemophilus inflfluenzae type b conjugate vaccine. Prog. Microbiol. Immunol. 2012, 5, 12.

104. Jones, A. Killer plastics: Antimicrobial additives for polymers. Plast. Eng. 2008, 64, 34-40. [CrossRef]

105. Sierra, J.M.; Viñas, M. Future prospects for Antimicrobial peptide development: Peptidomimetics and antimicrobial combinations. Expert Opin. Drug Discov. 2021, 601-604. [CrossRef] [PubMed] 